\title{
PSIHOLOŠKO DELOVANJE - VOJAŠKO DELOVANJE ALI UPORABNA SOCIALNA PSIHOLOGIJA?
}

\section{PSYCHOLOGICAL OPERATIONS - MILITARY OPERATIONS OR APPLICABLE SOCIAL PSYCHOLOGY?}

Povzetek Psihološko delovanje je pogosto razumljeno kot povsem vojaška vsebina, ki z znanostjo in stroko nima prave zveze. Vendar so v ozadju vojaških aktivnosti individualni in skupinski psihološki procesi, razumevanje katerih omogoča bistveno večjo učinkovitost delovanja. Gre za procese, na katerih temeljijo tudi aktivnosti, s katerimi se srečujemo vsak dan, ne da bi o tem kadar koli razmišljali - marketing, informativni programi, reklamiranje, medijske kampanje.

Članek osvetljuje področje psihološkega delovanja z različnih vidikov: z vidika vojaških ved, socialne psihologije ter psihologije tržnega komuniciranja. Pri tem poskuša definirati tako posebnosti, ki so značilne za vsakega izmed navedenih področij, kot tudi določiti skupno polje delovanja oziroma nekakšen presek množic. Poseben segment je namenjen študiji primera zgibanke, uporabljene na Kosovu leta 2007, ki je kot »vojaška aktivnost« analizirana $\mathrm{z}$ vidika socialne psihologije in psihologije (tržnega) komuniciranja.

Ključne

Psihološko delovanje, oborožene sile, socialna psihologija, komunikacija, mediji.

besede

Abstract Psychological operations are often seen as a purely military subject with no real relation to science and profession. However, the background of military activities includes individual and group psychological processes the understanding of which enables a much better operational performance. This involves the processes underlying the activities we encounter every day without ever even thinking about it marketing, information programmes, advertising, and media campaigns.

The article highlights the areas of psychological operations from various aspects: military science, social psychology and psychology of marketing communication. In this respect, it, both, attempts to define the features specific to each of those areas, as well as to establish a common field of activity or some kind of intersection of all sets. A special part of the article is devoted to a case study of a leaflet used in Kosovo in 
2007, a »military activity«, which is analysed from the perspective of social psychology and psychology of marketing communication.

Key words Psychological operations, armed forces, social psychology, communication, media.

Uvod Že Immanuel Kant je sanjal o trajnem miru na svetu (www.earlymoderntexts.com), vendar je videti, da namesto trajnega stanja miru zemljo pretresajo trajni spopadi in vojne narodov, ki drugim poskušajo vsiliti lastne vrednote ali zadovoljiti svoje politične in/ali ekonomske interese. Samo od druge svetovne vojne je na različnih koncih sveta potekalo več kot 200 vojaških operacij, ki jim ni videti konca (www.eruditionline. com). Nasprotno, odpirajo se nova in nova krizna žarišča in ko gre za »vojaško« tehnologijo in strategijo - posebno, če sem vštejemo iznajdljivost v ozadju terorističnih dejanj - človekova domišljija ne pozna meja. Od visoko razvite računalniške tehnologije do improviziranih sredstev uničevanja, sestavljenih iz povsem vsakdanjih izdelkov za domačo rabo, ki ležijo po podstrešjih in kleteh. Je torej imel Clausewitz prav, ko je zapisal, da je vojna »zgolj nadaljevanje politike z drugimi sredstvi«?

Ne glede na to, kako vidimo vzroke za nastanek vojne ali dejanja, ki delujejo kot sprožilci, ne moremo mimo dejstva, da ima vsaka vojna, spopad, vojaška operacija ali pa teroristično dejanje tudi svojo psihološko dimenzijo. Da za vsakim dejanjem stoji človek s svojimi močnimi in šibkimi točkami. Ter da vsako dejanje za seboj potegne množice, ki so tako ali drugače prizadete. In prav »množice« - kot skupek posameznikov in kot posebna entiteta - so tiste, na katere želimo neposredno ali posredno vplivati. Eno zmed orodij vplivanja na množice je tudi psihološko delovanje kot majhen, a pogosto pomemben in učinkovit segment vojšakega delovanja v miru in vojni.

\section{METODOLOŠKO HIPOTETIČNI OKVIR}

Članek temelji na teoretičnih metodah dela, ki vključujejo zbiranje podatkov iz primarnih dostopnih virov, sekundarnih virov ter podatkov, dostopnih prek svetovnega spleta. Povsem »vojaške aktivnosti« so osvetljene z vidika socialne psihologije v najširšem smislu ter psihologije tržnega komuniciranja. Za razumevanje povezave med strogo teoretičnim (strokovnim) in povsem praktičnim (vojaškim) delom so v članek vključene osnovne definicije psihološkega delovanja, značilnosti ter aktivnosti, ki jih vojska izvaja »v blatu in prahu«.

Del analize in razprave je namenjen (1) študiji primera zgibanke Slovenske vojske na Kosovu. Leta 2007 je v okviru bojne skupine Sokol na Kosovu delovalo približno 600 pripadnikov SV in civilnih oseb iz Slovenije. V tem času je bila zaradi krepitve dobrih odnosov izvedena kampanja, v okviru katere je bilo natisnjeno in razdeljeno večje število zgibank. Omenjeno aktivnost lahko opredelimo kot eno bolj prepoznavnih samostojnih aktivnosti psihološkega delovanja SV na območjih kriznih Žarišč. 
Drugi del (2) je namenjen premisleku o tem, v katero stroko psihološko delovanje pravzaprav spada. Gre za povsem vojaško strategijo in taktiko, za uporabno socialno psihologijo ali psihologijo tržnega komuniciranja?

\section{PSIHOLOŠKO DELOVANJE}

\section{"Na svetu obstajata dve sili; sila meča in sila uma. Toda na dolgi rok sila uma vselej premaga silo meča." \\ Napoleon}

\subsection{Definicija psihološkega delovanja}

Psihološko delovanje je kot komponenta informacijskega delovanja v Doktrini SV (Furlan, 2006, 67) opredeljeno kot »načrtovana psihološka dejavnost v miru in vojni, usmerjena v sovražne, lastne ali nevtralne ciljne skupine $\mathrm{z}$ namenom vplivanja na njihovo stališče in vedenje v podporo doseganju političnih ali vojaških ciljev.« Cilj psihološkega delovanja je slabljenje sovražnikove volje do bojevanja, krepitev podpore in lojalnosti lastnih in prijateljskih ciljnih skupin ter pridobivanje naklonjenosti tistih, ki so neodločeni ali nevtralni.

Ameriška doktrina informacijskega delovanja (US, Joint Chiefs of Staff, 2006, II-1) psihološko delovanje definira kot »načrtovano delovanje za prenos izbranih kredibilnih informacij tujim prejemnikom z namenom vplivanja na čustva, motive, razumevanje in končno tudi vedenje tujih vlad, organizacij, skupin ali posameznikov«. Namen psihološkega delovanja je ustvariti ali okrepiti stališča in vedenja tujih populacij, in sicer tako, da bodo ta naklonjena ciljem vira sporočila.

Ker gre za pomemben medij, velja omeniti tudi eno od opredelitev z medmrežja, ki meni, da gre v primeru psihološkega delovanja za »psihološke aktivnosti in psihološko vojskovanje, ki zaokrožuje tiste politične, vojaške, ekonomske in ideološke aktivnosti, ki so načrtovane in izvedene, da bi pri sovražnih, nasprotnih, nevtralnih ali prijateljskih skupinah oblikovale čustva, stališča in vedenje, ki bo naklonjeno doseganju nacionalne politike in ciljev« (www.eruditiononline.com).

Lahko bi dejali, da se v večini opredelitev psihološkega delovanja ponavljajo nekateri skupni osnovni elementi:

- psihološko delovanje razumejo kot poskus vplivanja na posameznike in skupine,

- navadno se nanašajo na stališča in osnovne elemente stališč - kognitivni, afektivni, vedenjski,

- usmerjeni so na (bolj ali manj skrbno) izbrane ciljne populacije,

- v ozadju delovanja so prisotni interesi oziroma cilji, v smeri katerih naj bi vplivanje delovalo.

Psihološko delovanje je v vojaškem okolju (posebej v zadnjih letih) navadno razumljeno kot eno izmed stebrov in ključnih zmogljivosti informacijskega delovanja, tj. 
»načina bojnega in nebojnega delovanja, ki se izvaja v miru in vojni v podporo političnim ali vojaškim ciljem, za vplivanje na osebe, ki sprejemajo odločitve« (Furlan, 2006, str. 52). Poleg psihološkega delovanja koncept informacijskega delovanja vključuje še elektronsko bojevanje, omrežno bojevanje, zavajanje in varnostno delovanje (Paul, 2008).

V literaturi, ki obravnava psihološko delovanje, je pogosto uporabljana različna terminologija, ki je odvisna od aktualnih smernic, v katerih je nastajala, od virov, na katerih temelji, in od izbire avtorja. V kontekstu vojaških operacij tako lahko srečamo izraze, kot so psihološke operacije (angl. Psychological Operations ali kot kratica PSYOPS), psihološko bojevanje, psihološko delovanje, propaganda itn.

Arnejčič (2008, str. 281) psihološko vojskovanje opredeljuje kot širši pojem, katerega namen je poskus vplivanja na javnost oziroma javno mnenje in ga definira kot »načrtovano in ciljno usmerjeno dejavnost v vojni in miru, ki uporablja spoznanja psihologije, da vpliva na vedenje nasprotnih množic in posameznikov«, medtem ko gre pri propagandi za predstavitev konkretnega dogodka na način, ki bi lahko vplival na druge posameznike.

Čeprav med posameznimi pojmi lahko opredelimo razlike, polemiziranje o ustreznosti uporabe enega ali drugega termina ter ugotavljanje, koliko se posamezni pojmi vsebinsko prekrivajo ali gre celo za sopomenke, za potrebe članka ni posebej bistveno. V članku pretežno uporabljen pojem »psihološko delovanje« se nanaša na veljavno Doktrino SV (Furlan, 2006).

\subsection{Namen in cilji psihološkega delovanja}

Logika psihološkega delovanja poskuša slediti nekaterim osnovnim predpostavkam:

1. Vsaka vojaška aktivnost ima tudi svojo psihološko dimenzijo in v tem kontekstu lahko na različne populacije vpliva zelo različno, torej mora biti aktivnost skrbno načrtovana, mogoče posledice pa pretehtane z različnih vidikov. Če na primer vstopamo v miren zaselek tako, da jasno razkazujemo svojo moč, z oklepljenimi vozili, rožljajočim orožjem, grobo in neuvidevno, to objektivno predstavlja negativno konotiran dražljaj - grožnjo in ustrahovanje. In vendar ga bodo različne skupine lahko različno razumele. Nasprotniki kot pritisk, ki mu velja popustiti, ali pa poziv k negativnemu odgovoru, neopredeljeni morebiti zgolj kot ustrahovanje, ki si ga niso zaslužili in jih bo potisnil v obrambno držo, ter podporniki kot dolgo pričakovano rešitev.

2. Na ljudi (posameznike in skupine), na njihova stališča in vedenje je mogoče vplivati. Pri tem moramo vzeti v zakup, da prepričevanje ljudi ni »sprint«, ampak »tek na dolge proge«, med katerim moramo skrbeti za ohranjanje kontinuitete, konsistentnosti in kredibilnosti. 
Ustrezno načrtovano, koordinirano in izvajano psihološko delovanje naj bi pozitivno vplivalo na stališča različnih ciljnih populacij, pri čemer pozitivno pomeni v smeri zastavljenih ciljev in bi torej moralo (1) slabiti voljo nasprotnih ali potencialno sovražnih skupin, (2) krepiti naklonjenost prijateljskih skupin ter (3) pridobivati podporo tistih, ki se niso opredelile.

Namen aktivnosti psihološkega delovanja ni le informiranje - slednje je v domeni odnosov z javnostmi in sorodnih zmogljivosti -, temveč prepričevanje in usmerjanje izbrane ciljne populacije k izbiri (za nas oziroma vir sporočila) ustrezne rešitve. Prisotnost enot, ki izvajajo aktivnosti psihološkega delovanja na terenu, hkrati omogoča (vsaj posredno) komunikacijo med poveljnikom in prebivalstvom, vpogled v psihološki učinek drugih aktivnosti ter informacije o tem, kako se različne populacije na območju delovanja odzivajo. Predvsem neposredna komunikacija, medsebojno spoznavanje, vzpostavljanje pogojev za skupne izkušnje ter posledično približevanje stališč so hkrati temelj za ustvarjanje zaupanja. S tega vidika aktivnosti psihološkega delovanja, po možnosti podprte z ustreznimi dejavnostmi civilno-vojaškega sodelovanja, lahko delujejo tudi kot način zagotavljanja varnosti in zaščite lastnih sil.

Nekateri avtorji psihološko vojskovanje in/ali delovanje povezujejo izključno z namenom zlomiti voljo do vojskovanja ter vzpostaviti okoliščine, ki bodo okrepile pojav bojnega oziroma operacijskega stresa pri nasprotniku. In čeprav bi to veljalo za ozko gledano pojmovanje vojskovanja ob predpostavki, da gre za simetrično vojskovanje v bolj tradicionalnem smislu (vojska proti vojski), s tem, ko se na območju delovanja znajdemo med lokalnim prebivalstvom, katerega odnos do nas je lahko zelo zapleten, in navzkrižnim ognjem najrazličnejših interesov nasprotnikov in zaveznikov, psihološko delovanje zagotovo ni omejeno le na ustrahovanje.

\subsection{Psihološko delovanje včeraj, danes, jutri ...}

Z vse večjim uveljavljanjem in izpostavljanjem nekinetičnega vojskovanja ter širitvijo medijev in telekomunikacij v vse kotičke našega življenja se zdi, da gre pri psihološkem (in širše - informacijskem) delovanju za uporabo razmeroma novih metod. In vendar temu ni tako. Psihološko delovanje je eno najstarejših orožij v človekovem arzenalu, ki se je na takšen ali drugačen način uporabljalo že od nekdaj. Tako so iz zgodovine poznani primeri (predvsem druga svetovna vojna, Koreja, Vietnam itn.) uporabe propagande za doseganje vojaških in političnih ciljev na načine, ki niso bistveno drugačni od sedanjih, ohranile pa so se tudi nekatere oblike diseminacije (npr. letaki, posterji itn.) (www.psywar.com). Podobno kot pri trženju in potrošništvu se je skozi čas spreminjala predvsem tehnologija, medtem ko procesi, na katerih psihološko delovanje temelji, ostajajo isti. Ključni preskoki so se dogajali z razvojem, uporabo in širitvijo elektronskih medijev (TV-programi, medmrežje, socialna omrežja, pametni mobilni telefoni idr.), ki prepričevanje in vplivanje na posameznika in množice ter njihovo informiranost postavljajo v povsem nov kontekst. Tudi zato, ker od z informacijami in dobrinami prenasičenih prebivalcev razvitega dela sveta zahtevajo razumevanje, da hkrati obstaja mesto z več stotisoč prebivalci, kjer je električna energija dostopna le nekaj ur na dan, in področja, kjer večina 
informacij še vedno kroži prek neposredne komunikacije. Okolja vojaških operacij, v katerih delujeta Nato in OZN, ter pod njihovim okriljem tudi SV, tako pogosto predstavljajo kaotično in nedoumljivo kombinacijo primitivne plemenske ureditve in Facebooka.

Tako kot tehnologija, se je spreminjala tudi terminologija. Če smo pred desetletji pred TV-dnevnikom spremljali EPP - ekonomsko propagandni program - nas zdaj (tudi med oddajami) motijo »reklame «. Nekatere celo za iste proizvode kot takrat, ko smo jim poljudno ravno tako rekli »reklame«. Beseda propaganda je s padcem zidov in režimov postajala vse bolj politično nekorektna, nekakšen simbol manipuliranja in vsiljevanja ideologije. V sodobnem vojaškem okolju je dolgo skoraj ni bilo mogoče zaslediti in ravno tako se z njo le redko srečujemo v novejši strokovni literaturi. Ali, kot je ob neki priložnosti izjavil polkovnik Jack Summe, nekdanji poveljnik ene pomembnejših ameriških enot za psihološko delovanje: »svoje delovanje imenujemo operacije in njihovo propaganda«, čeprav gre za enake mehanizme. Izraz propaganda se ponovno pojavlja v novejših različicah temeljnih dokumentov nekaterih vojsk (npr. FM 3-05.30; Psychological Operations).

Bolj kot sam koncept in vsebina se torej spreminjata forma in terminologija. Če je bilo prej govora o propagandi, ki ima negativno konotacijo, zdaj govorimo o psihološkem in/ali informacijskem delovanju. Če so bili prej primarni mediji posredovanja informacij živi ljudje in pozneje tisk, radio in kino, se zdaj večina informacij posreduje prek nevidnih signalov - računalnikov, mobilnih telefonov, satelitov itn. Tehnološkemu napredku se (tudi na teh področjih) tudi vojske ne morejo ogniti; še več, prenekatera tehnologija je svoj zagon dobila prav zaradi potreb vojsk.

\section{PSIHOLOGIJA KOT TEMELJ PSIHOLOŠKEGA DELOVANJA}

\section{"Osvojite njihova srca in duše in misel bo sledila ... $"{ }^{1}$}

www.psywarrior.com

Dobro načrtovano in pripravljeno psihološko delovanje, ki naj podpira poveljnikovo namero ter vpliva na ciljne populacije v želeni smeri, temelji na osnovnih spoznanjih psihološke stroke ter nekaterih družboslovnih ved (kulturne antropologije, sociologije ipd.). Tako je nujno poznavanje nekaterih psihičnih pojavov in procesov kot tudi družbene dinamike.

\subsection{Nekateri psihološki pojmi kot temelj izbire in oblikovanja sporočila}

\section{Potrebe in motivi}

Zadovoljevanje potreb je eno ključnih gonil človekovega delovanja. Zvonarević (1984) potrebo definira kot stanje organizma ali socialno situacijo, ki obstaja neodvisno od posameznika, ki je v stanju porušenega biološkega ali socialnega ravnovesja.

\footnotetext{
»Win their hearts, and their souls and minds will follow ..."
} 
Abraham Maslow navaja pet osnovnih motivov oziroma temeljnih potreb, ki so pomembno gonilo človekovega vedenja (Musek, 1988, 1993; Lamovec, 1988), prek njih pa lahko razmeroma preprosto razložimo prenekatero dejanje. Po svoji pomembnosti se motivi razvrščajo v hierarhijo (slika 1), ki opredeljuje tudi odnose med njimi. Na človeka navadno deluje več kot le en motiv², ki si nemalokrat med seboj celo nasprotujejo. Medtem ko nekatere potrebe lahko vsaj začasno odložimo, v dani situaciji eden izmed motivov - dominantni motiv - navadno prevlada. Pomen, ki ga motivom pripisujemo, je odvisen od posameznikove osebnosti (nekateri ljudje imajo raje slabše plačano, manj ugledno službo z redno plačo in pogodbo za nedoločen čas - potreba po varnosti -, drugim pa je socialna varnost manj pomembna od prepoznavnosti, plače ipd. - potreba po ugledu) in tudi od zunanjih okoliščin. V razvitih kulturah je potreba po hrani večinoma zadovoljena in potisnjena $\mathrm{v}$ ozadje, na območjih, na katerih se ljudje še vedno srečujejo z lakoto in žejo, pa so fiziološke potrebe običajno dominantne.

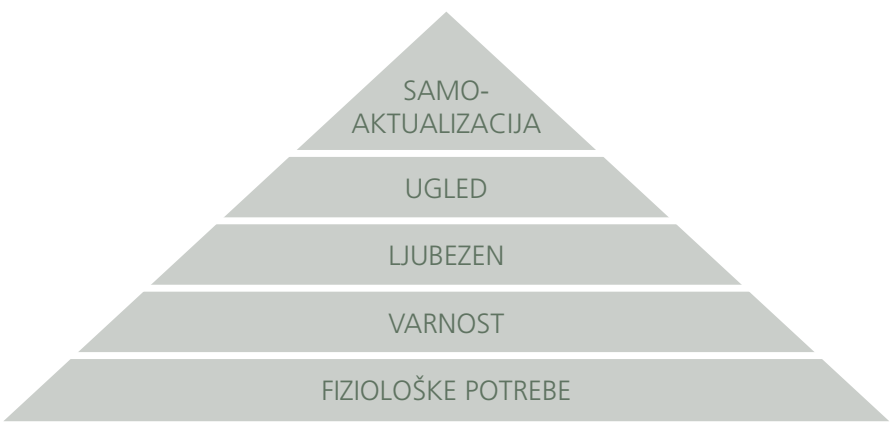

Vir: Musek, 1993 (str. 135).

Da bi s svojimi aktivnostimi in prizadevanji pritegnili pozornost ciljne populacije in jo zadržali, je pomembno, da z vsebino naslavljamo že obstoječe motive in potrebe, jih krepimo in posameznike usmerjamo k njihovemu zadovoljevanju. Če takšnega motiva ni ali v danih okoliščinah njegovo zadovoljevanje ni aktualno, ga ustrezno zapeljana kampanja lahko umetno ustvari oziroma okrepi. V vsakem primeru je razumevanje mehanizma zadovoljevanja človekovih potreb v luči aktualnih okoliščin in kulturnega ozadja na območju delovanja pomembno, da bi lahko razumeli odzive ljudi ter ustrezno načrtovali aktivnosti. Če moramo med prebivalci neke države ali območja nagovarjati predvsem občutek varnosti, ki ga ponuja sodelovanje, je morda ključnim posameznikom, vodjem, vaškim poglavarjem itn. te iste skupnosti pomembnejše od varnosti vzdrževanje ugleda, ki ga uživajo.

2 Tako imenovani motivacijski pluralizem, tj. sočasno delovanje več različnih motivov oziroma potreb na človeka v dani situaciji (Musek, 1993). 


\section{Pozornost}

Bagozzi (2002, str. 170) pozornost opredeljuje kot aktivnost, s katero posameznik osredotoča mentalno aktivnost na določen dražljaj. Pozornost je po svoji naravi selektivna, kar pomeni, da osredotočanje na nekatere dražljaje hkrati pomeni izključevanje drugih. Ule in Kline (1996) navajata različne vrste pozornosti, pri čemer so za tržno komuniciranje najpomembnejše (1) načrtna pozornost (posameznik išče določene informacije), (2) vsiljena pozornost, ki nastopi, ko se neki dražljaj vsili v našo zavest (na primer pok), ter (3) spontana pozornost, ki predstavlja nekakšno »odprtost « do dražljajev. Medtem ko se nakateri dejavniki pozornosti nanašajo predvsem na dražljaj (intenzivnost, prostornost, trajanje, pogostost, kontrast, gibanje itn.), drugi izhajajo iz prejemnika (izkušnje, interesi, potrebe, emocije itn.).

Pozornost je ključna sestavina kognitivnih procesov, ki sodelujejo pri procesiranju sporočila.

\section{Zaznavanje}

Zaznavanje je proces sprejemanja, predelave in primarnega interpretiranja informacij (Ule, 2009). Zaznavanje oziroma percepcija temelji na treh tipih dražljajev: (1) emocionalnih, (2) fizičnih ali (3) intelektualnih. Da bi pritegnili pozornost, se pri izvajanju aktivnosti psihološkega delovanja pogosto uporabljajo predvsem emocionalni dražljaji; tako pozitivni, ki naj bi delovali privlačno (slika idilične skupnosti, ki se bo ustvarila po prenehanju spopadov, ali pa - nam veliko bližja podoba - lepe ženske, ki sloni na visoko cenovnem avtomobilu itn.), kot tudi negativni, ki delujejo odbijajoče. Predvsem v začetnih fazah mirovnih operacij, ko je okolje še nestabilno in so napadi ter spopadi razmeroma pogosti, cilj pa stabilizacija in varnost, se v aktivnostih psihološkega delovanja pogosto pojavljajo izdelki, ki vključujejo zastraševanje, prisilo, diskreditacijo posameznikov (primer letaka, v katerem simbol Nata predstavlja merek na namerilni napravi). Medtem ko sta prisila in zastraševanje navadno usmerjena $\mathrm{v}$ nasprotnike, se $\mathrm{z}$ diskreditiranjem pomembnih posameznikov naslavljajo predvsem neodločene populacije.

Čustveno nabit dražljaj pritegne pozornost zaradi občutkov, ki jih generira, pozornost zadržuje, dlje pa se ohrani tudi v spominu. Podoben je učinek intelektualnih dražljajev, ki zahtevajo dodatno angažiranje kognitivnih funkcij - procesiranje posredovanega podatka. ${ }^{3}$

\section{Mišljenje}

Sporočilo, ki ga želimo posredovati, mora omogočati razumevanje ter biti oblikovano in posredovano na način, ki ni prezahteven za ciljno populacijo ali neusklajen z njenim načinom mišljenja in vrednotami in bi lahko bilo napačno razumljeno. Vsebine in tudi forme spoznavnih procesov se v različnih kulturah lahko bistveno

\footnotetext{
$V$ enem izmed okrajev $v$ ZDA so ob odsek ceste, kjer so se pogosto dogajale prometne nesreče s hudimi poškodbami ali smrtnim izidom, namesto oglasov postavili razbitine avtomobilov skupaj s tablo, na kateri so redno registrirali število nesreč v zadnjem letu na omenjenem odseku. Tako so združili uporabo emocionalnih in intelektualnih dražljajev.
} 
razlikujejo, saj so večinoma povezane s procesom socializacije (Zvonarević, 1984), ki poteka v nekem razmeroma omejenem okolju.

Nesmiselno je prebivalstvu posredovati bilten, v katerem so do potankosti opisane vse aktualne okoliščine, vključno z dejstvi, ki so jim sicer morda zamolčana, če je ta natisnjen v pisavi, ki ljudem ni poznana, če nismo upoštevali vprašanja pismenosti na splošno, če je vsebina zapisana v znanstvenem jeziku, ki preprostim ljudem ni razumljiv, in če so prezaposleni z zadovoljevanjem najbolj osnovnih življenjskih potreb.

\section{Spomin}

Spomin bi lahko opredelili kot posameznikovo sposobnost zadrževanja in hranjena informacij. Odvisen je tako od zaznavanja in pozornosti kot tudi od razumevanja. Poleg bioloških predispozicij na sposobnost pomnjenja vplivajo tudi predhodno znanje, stališča posameznika ter interesi (Zvonarević, 1984). Informacije, ki jih uporabljamo v kampanjah, morajo biti poudarjene na način, ki omogoča priklic sporočila tudi potem, ko posameznik sporočilu ni več izpostavljen. Ohranjanje informacij lahko zagotovimo že z uporabo ličnega slikovnega materiala, h kateremu nam uide pogled oziroma nam pritegne pozornost, lahko pa funkcijo še okrepimo, če mu dodamo informacije, ki nagovarjajo tudi druge čute, na primer z zvokom. Tako kot pri percepciji imajo pomembno vlogo tudi čustva in intelekt.

Omejitve človekovega spomina lahko do neke mere kompenziramo z ustrezno izbiro medija. Tiskani mediji tako zagotavljajo trajnost informacije, saj jo lahko prejemnik praktično kadar koli in kjer koli obnovi, ne omogočajo pa razkošja večpredstavnosti in celo interaktivnosti modernih elektronskih medijev.

\section{Čustva}

Če se večji del omenjenih pojmov iz sveta človekove duše nanaša na kognitivne procese in spoznavne funkcije, pa človek vendarle ni le »umni človek«. Njegovo življenje in delovanje opredeljujejo tudi čustva. Čustva predstavljajo duševno stanje pripravljenosti, ki izhaja iz kognitivne ocene dogodkov ali misli, je fenomenološko obarvano, spremljajo ga fiziološki procesi, je pogosto tudi fizično izraženo in lahko rezultira $\mathrm{v}$ specifične aktivnosti, katerih cilj je potrditev ali poskus obvladovanja čustva (Bagozzi, 2002, str. 172).

Ste se kdaj zalotili, da vas storitev ni pustila zadovoljene, čeprav je bila povsem korektno in pravilno opravljena? V potrošništvu čustva delujejo kot markerji, mediatorji in moderatorji našega vedenja, vplivajo pa tudi na kognitivne funkcije - na spomin, procesiranje informacij in presojanje ter ne nazadnje tudi na zadovoljstvo (Bagozzi, 2002).

\section{Stališča}

Krech, Crutchfield in Ballachey (v Ule, 2009) stališča definirajo kot trajne sisteme pozitivnega ali negativnega ocenjevanja, občutenja in aktivnosti $\mathrm{v}$ odnosu do različnih socialnih situacij in objektov. Stališča sestavljajo tri ključne komponente: 
(1) kognitivna, kot so znanje, izkušnje, sodbe in informacije o vsebini (mišljenje), (2) čustvena ali afektivna, ki se nanaša na pozitivno ali negativno naravnanost do obravnavane vsebine (čustva), ter (3) motivacijska, ki se kaže v težnji po delovanju na določen način (vedenje).

Stališča so naučena in kot takšna podvržena spreminjanju pod vplivom prepričevanja, s tem pa tudi orodje, prek katerega poskušamo usmerjati vedenje ljudi.

\section{Predsodki}

Predsodki so razmeroma trdna stališča do socialnih situacij, ki temeljijo na nepreverjenih dejstvih, in so pogosto globoko ukoreninjena v posameznikovo zavest. Gre za poenostavljene strukture, ki povzročajo selektivno pozornost ter popačenje določene vsebine (Ule, 2009). Verjetno ni treba posebej poudarjati, da aktivnosti, ki temeljijo na predsodkih, dejansko temeljijo na popačenih informacijah.

V okolju vojaških operacij moramo o predsodkih razmišljati z dveh vidikov. Po eni strani je bistveno, da prevetrimo svoj lastni nabor predsodkov, ki bi nam v kulturno raznolikem okolju lahko predstavljal ovire v komunikaciji, vplival na našo naklonjenost do določenih skupin prebivalstva, ne nazadnje ogrozil naše delovanje. Po drugi strani mora naša analiza ciljne populacije upoštevati tudi predsodke, ki bi jih prebivalstvo lahko imelo do nas, kar se bo v najboljšem primeru kazalo kot naša popolna neučinkovitost, lahko pa ogrozi tudi našo varnost ${ }^{4}$.

\section{Vedenje}

Cilj psihološkega delovanja je sprememba vedenja, torej mora sporočilo vzbujati občutke in dajati informacije, ki posameznika v končni fazi usmerijo k želenemu cilju.

\subsection{Poznavanje ciljne populacije - ustreznost izbire}

Analiza ciljne populacije predstavlja enega ključnih elementov v procesu razvoja ustreznega izdelka, nanaša pa se predvsem na izbor sporočil, ki bodo ustrezno izkoriščala osnovne psihične procese, hkrati pa se bodo s svojo simboliko in vsebino kar najbolj približala osnovnim značilnostim skupin, ki so jim namenjena. Analiza vključuje tako politično-vojaške dejavnike (ideologija, naravno okolje, politični sistem, zgodovina, religija, vloga medijev, vodstvo, kulturno okolje itn.) kot tudi psihološke in sociološke dejavnike (vrednote, stališča, predsodke, kulturo, pomembne socialne skupine, družbeno in skupinsko dinamiko, ključne posameznike itn.).

Analiza ciljne populacije temelji na petih elementih, ki so prikazani na primeru spodbujanja ženske populacije k udeležbi na volitvah:

- prepoznavanje vrednot ciljne populacije; kakšna je vloga ženske v dani kulturi, je spoštovana, upoštevana, enakovredna članica skupnosti;

\footnotetext{
${ }^{4}$ Na območju Afganistana je bila zaradi razbijanja predsodkov, ki jih je zaradi slabih izkušenj lokalno prebivalstvo imelo do uniformiranega osebja, izpeljana kampanja, v kateri so bile predstavljene nekatere članice koalicije, in sicer tako, da so bile jasno prikazane razlike med uniformami in oznakami.
} 
- preverjanje ravni odrekanja, ki ga zahteva sprememba vedenja; ženska se na podlagi nagovarjanja odloči za udeležbo na volitvah, kar ima za posledico nasilje moških članov družine nad njo;

- zagotavljanje razumevanja pomena novega (želenega) vedenja; kako se bodo z udeležbo žensk spremenile okoliščine v državi, kaj konkretno to pomeni za skupnost, družino, posameznika;

- učinkovitost prenosa koristi novega vedenja; ali, glede na značilnosti dane kulture, koristi novega vedenja lahko prenesemo na posameznike? Ali na primer v Afganistanu, ki ga poseljujejo različne etnične skupnosti, povprečna (nešolana) ženska razume koncept države in vlade?;

- preverjanje, ali je sprememba vedenja v danih okoliščinah za ciljno populacijo sploh mogoča - ali se ženska, ki smo jo nagovorili, sploh lahko (fizično) udeleži volitev? Ali bo že zaradi stika z nami ustrahovana ali izolirana?

S svojimi postopki in metodami se tako psihološko delovanje v vojaškem okolju vse bolj približuje konceptom, ki se uporabljajo na področju oglaševanja in trženja (Department of the Army, 2003).

Ker (navadno) izhajamo iz drugačnih socialno kulturnih in ekonomskih okoliščin kot ciljne populacije, s katerimi se srečujemo na kriznih žariščih, ne smemo pozabiti tudi na tako banalna vprašanja, kot je možnost dostopa do radijskega sprejemnika, kaj šele računalniške tehnologije in interneta.

\subsection{Komunikacija - od oddajnika k prejemniku}

Če smo si skozi prizmo socialne psihologije ogledali sporočilo in ciljno populacijo, velja spregovoriti tudi o procesu, ki poteka med oddajnikom in prejemnikom.

O komuniciranju govorimo takrat, ko med partnerji v socialni interakciji poteka kontinuiran tok sporočil (Ule in Kline, 1996; Adler, Rodman v Ule, 2005), ki so podana v nekem kodu, znakovnem sistemu, ki omogoča prenašanje pomena. Komuniciranje praviloma poteka $\mathrm{v}$ kontekstu nekih okoliščin, ki proces pošiljanja in prejemanja naredi bistveno bolj zapleten.

Glede na odnos med partnerji se komuniciranje deli na (1) znotrajosebno (proces predelave informacij v posamezniku), (2) medosebno, pri katerem gre za izmenjavo informacij med posamezniki, ter (3) nadosebno ali množično komuniciranje, ki je lahko skupinsko ali pa množično (Ule in Kline, 1996). Aktivnosti psihološkega delovanja med drugim predvidevajo tudi osebne stike, ki vključujejo predvsem neposredno komuniciranje taktičnih skupin z lokalnim prebivalstvom, ter komuniciranje poveljujočih s ključnimi lokalnimi osebami in s tem medosebno komunikacijo. Večina sporočil pa je vendarle posredovana prek drugih medijev in torej spada $\mathrm{V}$ področje množičnega komuniciranja. 


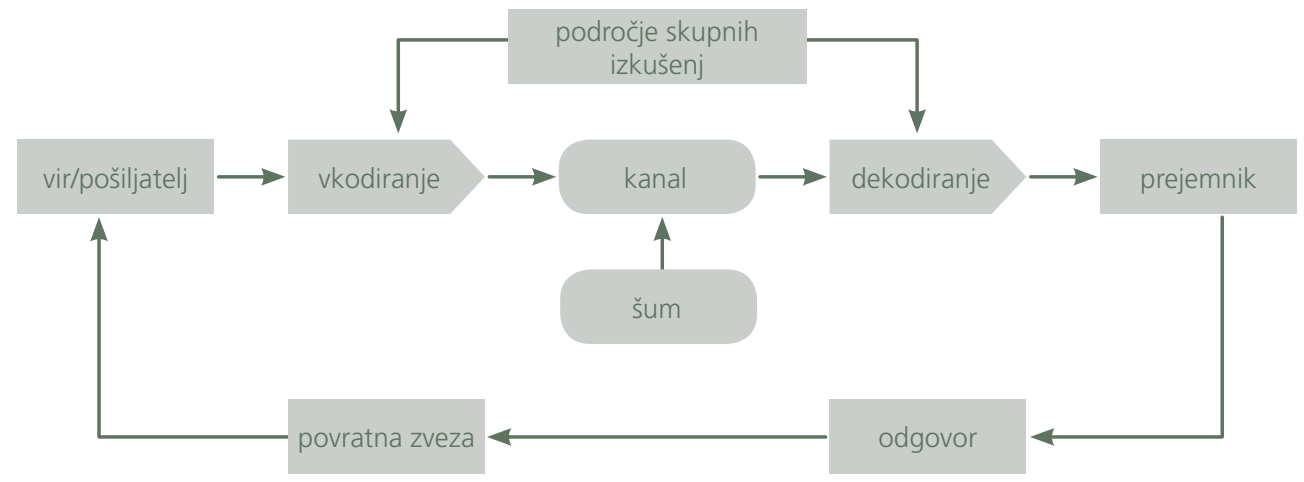

Slika 2 shematično ponazarja Schramov model (uspešnega) komuniciranja, iz katerega je mogoče izpeljati tri osnovne pogoje za učinkovitost: (1) sporočilo mora biti oblikovano in posredovano tako, da vzbudi zanimanje prejemnika, (2) vsebovati mora znake, ki so skupni in/ali razumljivi tako viru kot prejemniku, ter (3) nasloviti potrebe prejemnika (Ule in Kline, 1996).

Če stopimo korak nazaj, bomo videli, da vse podatke, ki jih zahteva uspešno komuniciranje, lahko najdemo v ustrezno zastavljeni analizi ciljne populacije, ki upošteva vse psihodinamične in sociodinamične elemente neke skupine, kulture in družbe.

\section{RAZVOJ IZDELKA}

"Ko ustvarjamo stvari, je to zato, ker poslušamo kupca, poberemo njihove predloge in dodamo še tisto, kar bi sami radi videli. Skuhamo nove izdelke. In v resnici nikoli ne veš, ali jih bodo ljudje imeli tako radi kot ti. $\|^{5}$

\section{Steve Jobes}

Psihološko delovanje predstavlja neskončen proces načrtovanja, analiziranja, usklajevanja, razvijanja, produciranja, distribuiranja in vrednotenja izdelkov ter aktivnosti, s katerimi želimo vplivati na ciljno populacijo. Razvoj ustreznega izdelka oziroma kampanje vključuje nekatere temeljne procese, ki se med seboj nadgrajujejo in dopolnjujejo:

- načrtovanje in oblikovanje programov (namera poveljnika, analiza ciljev konkretne operacije, oblikovanje konceptov v najširšem smislu, usmerjanje itn.),

\footnotetext{
5 »When we create stuff, we do it because we listen to the customer, get their inputs and also throw in what we'd like to see, too. We cook up new products. You never really know if people will love them as much as you do"
} 
- analiza ciljne populacije,

- razvoj izdelka na podlagi vseh prepoznanih dejavnikov (na splošno se delijo na tiste, ki izhajajo iz misije, ter tiste, ki izhajajo iz ciljne populacije),

- testiranje in evaluacija izdelka, ki vključuje predhodno testiranje na ustreznem vzorcu ali v okviru fokusne skupine pred produkcijo (usmerjeno predvsem na ustreznost produkta) ter evaluacijo učinka že izvedene naloge v luči doseganja želenega cilja,

- diseminacijo oziroma posredovanje sporočila prek ustrezno izbranega medija (Department of the Army, 2003).

Omenjeni procesi se, posebej v primeru večjih vojsk, pogosto prekrivajo s formalno organizacijo enot, katerih osnovno poslanstvo je izvajanje psihološkega delovanja.

\section{ORODJA DELOVANJA}

"Besede so novo orožje, sateliti nova artilerija ... Cezar je imel svoje častnike. Napoleon svojo armado. Jaz imam svojo divizijo: televizijo, časopise, revije .... $\|^{6}$ Archivilliain Elliot v filmu J. Bond: Jutri nikoli ne umre

Orodje delovanja na področju psihološkega delovanja podobno kot v tržnem komuniciranju predstavljajo vsa tehnična ali netehnična sredstva, prek katerih lahko poteka proces komunikacije s ciljno populacijo ali posamezniki. Z razvojem informacijske tehnologije se možnosti širijo, in tako se ob tiskanih produktih in različnih uporabnih izdelkih, kot so svinčniki, papirnati zmaji, kape ipd., vse bolj uveljavljajo različne oblike elektronskih medijev in množičnih občil. Medije, ki se uporabljajo za potrebe psihološkega delovanja, lahko kategoriziramo v tri osnovne skupine: (1) vizualni mediji, (2) avdio, (3) avdiovizualni, ki pritegnejo tako vid kot sluh (televizija, računalnik, pametni telefoni idr.) (www.psywarrior.com). Slednji s svojimi možnostmi uporabe (posebej v razvitih deželah in krajih) prodirajo v vse kotičke življenja. V primerjavi s prvimi oblikami, kot sta televizija ali kino, internet uporabnika iz vloge pasivnega opazovalca, ki informacije le sprejema, postavlja v vlogo partnerja, ki v odnosu lahko aktivno sodeluje.

Kot poseben način delovanja, ki ne spada v nobeno izmed naštetih kategorij, lahko omenimo še neposredno komunikacijo (angl. face-to-face communication) ter delovanje prek ključnih oseb (angl. key-leaders engagement) ${ }^{7}$. Prvi primer bi lahko primerjali s posrednikom ali prodajalcem, ki hkrati s prodajo storitve ali izdelka izvaja tudi anketiranje (ali obratno, poskuša prek ankete prodati izdelek), ali takšnim, ki svoje storitve ponuja prek organiziranih predstavitev javnega ali zaprtega tipa. V drugem primeru se način delovanja približuje modelu večfaznega komuniciranja - poleg delovanja prek drugih

\footnotetext{
Vir: Arnejčič, 2008, str. 283.

Ključne osebe, pripadnike neke skupine (npr. poglavar vasi itn.), se pogosto uporabljajo kot »medij«za prenos sporočil, kar pa je izvedljivo le pod pogojem, da oseba, s katero komunicira, uživa veliko zaupanja in kredibilnosti, kar je zaradi narave operacij (kratkotrajne rotacije) pogosto težko doseči. Ustrezna komunikacija in zaupanje sta pogosto odvisna tudi od osebnostnih lastnosti in spretnosti posameznika (praviloma častnika višjega ranga, ki uživa ugled), ki stopa v stik s ključnimi osebami.
} 


\begin{tabular}{|c|c|c|c|c|c|}
\hline $\begin{array}{r}\text { Tabela 1: } \\
\text { Nekatere } \\
\text { značilnosti }\end{array}$ & & MEDIJ & $\begin{array}{l}\text { NEKATERE } \\
\text { ZNAČILNOSTI }\end{array}$ & PREDNOSTI & POMANJKLIVOSTI \\
\hline $\begin{array}{l}\text { posameznih } \\
\text { medijev (www. } \\
\text { psywarrior.com) }\end{array}$ & \multirow{3}{*}{$\begin{array}{l}\text { VIZUALNI - } \\
\text { TISKANI }\end{array}$} & PLAKAT & $\begin{array}{l}\text { enostranski, } \\
\text { statičnost - publika } \\
\text { so le mimoidoči }\end{array}$ & $\begin{array}{l}\text { nizki stroški, } \\
\text { trajnost, ciljna } \\
\text { usmerjenost - } \\
\text { točno določena } \\
\text { populacija }\end{array}$ & $\begin{array}{l}\text { hitrost/ažurnost prenosa, } \\
\text { dolgotrajna distribucija, } \\
\text { podvržena trenutni situaciji, } \\
\text { pogosto predvideva } \\
\text { pismenost }\end{array}$ \\
\hline & & LETAK & $\begin{array}{l}\text { dvostranski, } \\
\text { mobilnost, } \\
\text { mogoče uporabiti/ } \\
\text { prebrati kadar koli, } \\
\text { enotne velikosti } \\
\text { in oblike, mogoča } \\
\text { diseminacija iz } \\
\text { zraka }\end{array}$ & $\begin{array}{l}\text { nizki stroški, } \\
\text { trajnost, ciljna } \\
\text { usmerjenost - } \\
\text { točno določena } \\
\text { populacija }\end{array}$ & $\begin{array}{l}\text { hitrost/ažurnost prenosa, } \\
\text { dolgotrajna distribucija, } \\
\text { podvržena trenutni situaciji, } \\
\text { pogosto predvideva } \\
\text { pismenost, mogoča } \\
\text { izpostavljenost posameznika, } \\
\text { ki ga poseduje }\end{array}$ \\
\hline & & $\begin{array}{l}\text { PERIODIČNI } \\
\text { TISK }\end{array}$ & $\begin{array}{l}\text { obsežnejše } \\
\text { besedilo, izdaja v } \\
\text { rednih časovnih } \\
\text { obdobjih }\end{array}$ & $\begin{array}{l}\text { nizki stroški, } \\
\text { trajnost, ciljna } \\
\text { usmerjenost - } \\
\text { točno določena } \\
\text { populacija, } \\
\text { ustvarjanje navad }\end{array}$ & $\begin{array}{l}\text { hitrost/ažurnost prenosa, } \\
\text { dolgotrajna distribucija, } \\
\text { podvržena trenutni situaciji, } \\
\text { zahteva pismenost, mogoča } \\
\text { izpostavljenost posameznika, } \\
\text { ki ga poseduje }\end{array}$ \\
\hline & \multirow[t]{2}{*}{ AVDIO } & RADIO & $\begin{array}{l}\text { širok doseg, ažurna } \\
\text { uporaba novih } \\
\text { informacij, možnost } \\
\text { oddajanja iz zraka }\end{array}$ & $\begin{array}{l}\text { doseg, pokritost, } \\
\text { pravočasnost, } \\
\text { domačnost, } \\
\text { raznolikost, } \\
\text { hitrost, ne zahteva } \\
\text { pismenosti }\end{array}$ & $\begin{array}{l}\text { tehnična oprema, } \\
\text { možnost (namernega ali } \\
\text { nenamernega) motenja, } \\
\text { razpoložljivost sprejemnikov, } \\
\text { frekvence, napajanje, } \\
\text { minljivost, konkurenca, } \\
\text { neselektivnost }\end{array}$ \\
\hline & & $\begin{array}{l}\text { SISTEMI } \\
\text { OZVOČENJA }\end{array}$ & $\begin{array}{l}\text { »neposreden« stik, } \\
\text { odzivnost }\end{array}$ & $\begin{array}{l}\text { selektivnost, } \\
\text { preprostost, } \\
\text { mobilnost, hitrost, } \\
\text { ne zahteva } \\
\text { pismenosti }\end{array}$ & $\begin{array}{l}\text { ranljivost, fizične ovire, } \\
\text { izpostavljenost, minljivost }\end{array}$ \\
\hline & \multirow{3}{*}{$\begin{array}{l}\text { AVDIO- } \\
\text { VIZUALNI }\end{array}$} & TELEVIZIJA & $\begin{array}{l}\text { vplivnost, intimnost, } \\
\text { vzpostavljanje } \\
\text { navad }\end{array}$ & $\begin{array}{l}\text { hitrost, ne zahteva } \\
\text { pismenosti, } \\
\text { manj odvisna od } \\
\text { tradicionalnih } \\
\text { vzorcev }\end{array}$ & $\begin{array}{l}\text { doseg, draga oprema in } \\
\text { vzdrževanje, specializirana } \\
\text { ekipa, nestalnost, } \\
\text { razpoložljivost }\end{array}$ \\
\hline & & $\begin{array}{l}\text { KINEMATO- } \\
\text { GRAF }\end{array}$ & $\begin{array}{l}\text { spoti in izvlečki, } \\
\text { popularen na } \\
\text { območjih brez TV }\end{array}$ & $\begin{array}{l}\text { vtis verodostojnosti, } \\
\text { ne zahteva } \\
\text { pismenosti, } \\
\text { čustvena } \\
\text { identifikacija, velika } \\
\text { stopnja priklica }\end{array}$ & $\begin{array}{l}\text { stroški, počasnost in } \\
\text { neažurnost, možnost cenzure } \\
\text { in restrikcije }\end{array}$ \\
\hline & & INTERNET & $\begin{array}{l}\text { aktivno iskanje } \\
\text { informacij, različne } \\
\text { oblike omogočajo } \\
\text { možnost široke } \\
\text { publike ali ozko } \\
\text { usmerjenost (npr. } \\
\text { klepetalnica) }\end{array}$ & $\begin{array}{l}\text { neomejen doseg, } \\
\text { hitrost in takojšnja } \\
\text { dostopnost, } \\
\text { možnost } \\
\text { delovanja z velike } \\
\text { oddaljenosti, nizki } \\
\text { stroški }\end{array}$ & $\begin{array}{l}\text { problem nepredvidenih } \\
\text { populacij, dostopnost } \\
\text { računalnikov in internetnih } \\
\text { storitev, zahteva pismenost, } \\
\text { anonimnost, konkurenca, } \\
\text { izpostavljenost sporočil }\end{array}$ \\
\hline
\end{tabular}


sredstev je ključnega pomena angažiranje vplivnih posameznikov. Ti so v manj razvitih okoljih in kulturah pogosto ključni dejavnik odločanja tako skupnosti kot posameznika.

V tabeli 1 so strnjene nekatere temeljne značilnosti uporabe in prednosti ter pomanjkljivosti posameznih sredstev komunikacije.

Nekatera sredstva na določenih območjih niso dostopna ali pa je njihova (ne)uporaba odvisna od tamkajšnje kulture, zato je izbira ustreznega medija ena ključnih točk v procesu načrtovanja. Izkušnje kažejo, da je pri tem pomembna temeljita analiza, ki se ji pogosto nameni premalo pozornosti. Tako se je izkazalo (na presenečenje nekaterih pripadnikov tujih - predvsem zahodnih vojsk), da so dostopnost medijev in navade prebivalcev Bosne in Hercegovine bistveno bolj podobne tistim v razvitih deželah kot deželam tretjega sveta (Larsen, 1999).

Da bi bilo sporočilo kar najbolj učinkovito, se v okviru kampanj pogosto uporabi kombinacija različnih načinov prenosa informacij, ki se med seboj podpirajo in dopolnjujejo (na primer letaki, ki poleg sporočila objavljajo radijsko frekvenco).

\section{6 ŠTUDIJA PRIMERA - UPORABA PRINCIPOV PSIHOLOŠKEGA DELOVANJA V SLOVENSKI VOJSKI}

\section{"Nisem ustrelil s puško. Naredil sem ji promocijo. $\|^{8}$ \\ Jared Kintz}

Angažiranje Slovenske vojske na področju psihološkega delovanja na območjih operacij kriznega odzivanja je bilo do zdaj bolj ali manj omejeno na sodelovanje $\mathrm{v}$ mednarodnih poveljstvih in enotah; večji del s posamezniki ali manjšimi enotami, katerih naloge so bile omejene na posamezen segment psihološkega delovanja. Obstaja pa primer tiskanega izdelka, ki sledi ideji psihološkega delovanja in je bil izdelan in uporabljen na območju Kosova leta 2007.

Zgibanka, predstavljena med slikami, je bila izdelana pod okriljem aktivnosti, ki so jih poimenovali z delovnim naslovom »Wining hearts and minds«. Enota je aktivnosti začela izvajati potem, ko je prevzela območje delovanja ter se ustalila $\mathrm{v}$ okviru svojih nalog. Osnovni cilj aktivnosti je bil vzpostaviti še boljše sodelovanje z lokalnim prebivalstvom ter pridobiti informacije o tem, kako lokalno prebivalstvo dojema in sprejema prisotnost slovenskih vojakov. V ozadju te konkretne aktivnosti pa je bistveno širša ideja, da bo z »osvajanjem src in duš« lokalnega prebivalstva ter krepitvijo njihove naklonjenosti večja tudi varnost slovenskih vojakov. Zgibanko so pripadniki delili prebivalcem, s katerimi so prihajali $\mathrm{v}$ neposreden stik na kontrolnih točkah ali v okviru drugih nalog. Napisana je bila v albanskem, srbskem in angleškem jeziku v dveh vsebinsko zelo podobnih različicah (Škerbinc, 2013).

8 »I didn't fire a gun. I gave it a promotion." 
Naslovnica tridelne zgibanke je namenjena pozdravu in nagovoru. S poudarjenim naslovom na rdeči podlagi, katerega namen je pritegniti pozornost, piše "POZDRAVLJENI! ${ }^{\prime}$ ", ter v nadaljevanju: »Ustavili smo vas na kontrolni točki ali pa ste na kakšen drug način prišli v stik z vojakom Kforja-pripadnikom slovenskega kontingenta, ki deluje v okviru bojne skupine Sokol, ki je del mednarodnih sil. Naša naloga v okviru Kforja je, da vsem prebivalcem Kosova zagotovimo varno okolje."

Tako na zunanji kot tudi na notranji strani je uporabljen slikovni material, ki se nanaša na delo pripadnikov SV in njihovo mednarodno in civilno-vojaško sodelovanje. Na obeh straneh se večkrat ponovita kratici Nato in Kfor ter oznake slovenskega kontingenta v različnih oblikah in izvedbah (zastava, grb SV v vodnem tisku ipd.). Tako se vzpostavlja prepoznavnost in kredibilnost vira, ki nima nikakršnega interesa prikrivanja svoj identitete, saj se pojavlja z odkritimi in poštenimi nameni (t. i. »beli« PSYOPS $^{10}$ ).

Druga stran izdelka povzema in dodatno razčlenjuje nagovor na naslovnici: »V bojni skupini Sokol je aktiven slovenski bataljon, ki mu je pridodana madžarska četa. Vsi ti vojaki imajo izkušnje z več mirovnih operacij. Na Kosovu tako trenutno deluje več kot 600 vojakov ter civilnih strokovnjakov, kot so inženirji, veterinarji in zdravniki. Vsi skupaj si želimo, da bi živeli v sodobnem in gostoljubnem okolju. Preteklosti žal ne moremo spremeniti, lahko pa vplivamo na svetlejšo prihodnost.«

Del zgibanke je namenjen povratnim informacijam lokalnega prebivalstva, tj. ciljne populacije, o delovanju pripadnikov slovenskega kontingenta. "Zanima nas vaše mnenje o odnosu naših vojakov v vašem okolju. Priporočamo se za vsako informacijo, kritiko, mnenje ali pohvalo. «

Zgibanka z obliko in vsebino nagovarja z vsemi tremi tipi dražljajev, na katerih temeljijo zaznavni procesi.

(1) Čustvovanje; fotografije iz vsakdanjega življenja pripadnikov so večinoma zaznamovane s pozitivnimi emocijami in prikazujejo dobre medsebojne odnose in komunikacijo med pripadniki in lokalnim prebivalstvom. Dodatno čustveno noto jim dajejo fotografije otrok, ob katerih se še posebej hitro raznežimo. Te so tudi v oglaševanju pogosto uporabljene prav zaradi vzbujanja pozitivnih emocij.

(2) Poskus aktivacije zaznavnih procesov prek fizičnih dražljajev (v tem primeru vizualnih) je opazen predvsem na naslovnici, kjer pozornost pritegne krepko tiskan pozdrav. Podobno vlogo ima tudi uporaba slikovnega materiala, ki našo pozornost pritegne bistveno bolje od dolgega in drobnega besedila, ki zahteva dodatno angažiranje.

\footnotetext{
9 Uporabljen je neuraden prevod albanskega primera zgibanke.

${ }^{10}$ Psihološko delovanje se z vidika navajanja vira deli na »belo« - aktivnost je označena s pravim virom, »sivo«, pri čemer vir ni naveden, ter »črno« - aktivnost je namerno pripisana drugemu (Paul, 2008). Aktivnosti oboroženih sil naj bi potekale zgolj $v$ »belem polju«.
} 
(3) Miselni del zajema besedilo, ki v nekaj preprostih stavkih opisuje namen sodelovanja slovenskega kontingenta in Kforja na Kosovu ter postopno in nevsiljivo poskuša usmeriti posameznika k (skupnemu) cilju v ozadju. V tem delu besedila so razčlenjena nekatera dejstva o prisotnosti slovenskega kontingenta na Kosovu.

Z majhnimi oblikovnimi in vsebinskimi razlikami sta različici, ob tem da so bila osnovna sporočila ohranjena, pri lokalnem prebivalstvu spodbudili zanimanje in željo po prejemu obeh (Zakaj je njegova drugačana od moje?), tako je bila zagotovljena tudi večja verjetnost, da bo prejemnik besedilo prebral.

Skozi celoten izdelek se ponavljajo simboli, katerih namen je prepoznavnost ter transfer pozitivnih emocij:

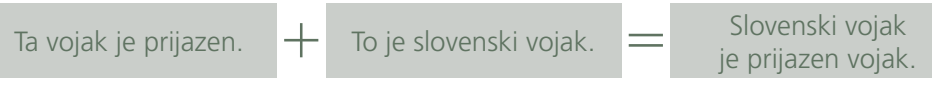

Če izhajamo iz potreb, lahko izločimo predvsem motiv varnosti v najširšem smislu (preprečevanje neposredne ogroženosti, vzpostavljanje varnih zatočišč in domov itn.), ki jo implicira tako v besedilu kot tudi v slikovnem materialu, in nakazuje, da bo s sodelovanjem ta potreba zadovoljena.

Ob upoštevanju dveh ključnih entitet, Srbov in Albancev, je bila enaka zgibanka natisnjena $\mathrm{v}$ obeh jezikih, s čimer je bila poudarjena nepristranska drža slovenskih pripadnikov.

Zgibanka omogoča grobo analizo tudi z vidika procesa komunikacije. Slika 4 predstavlja shematski prikaz osnovnega modela procesa komuniciranja ob upoštevanju ključnih elementov.

Kot vir se v tem primeru pojavlja slovenski kontingent, ki zaupanje gradi na kombinaciji slikovnega gradiva in besedila, v katerem je implicirano dosedanje dobro sodelovanje. Sporočilo, ki ga želi prenesti, je, da se zanima za blaginjo prebivalstva, mu želi pomagati, in z njihovim sodelovanjem pogoje za življenje še izboljšati. Večina prejemnikov, ki so se (prek povratne zveze) odločili odgovoriti na sporočilo, so izražali naklonjenost do prisotnosti Slovencev in Kforja na Kosovu. Torej lahko sklepamo, da je bilo sporočilo razumljeno podobno, kot je bilo zamišljeno - med slovenskim kontingentom in lokalnim prebivalstvom je vzpostavljen dober odnos. 
Slika 4:

Shematski prikaz osnovnega modela procesa komuniciranja na primeru (prirejeno po Ule in Kline, 1996)

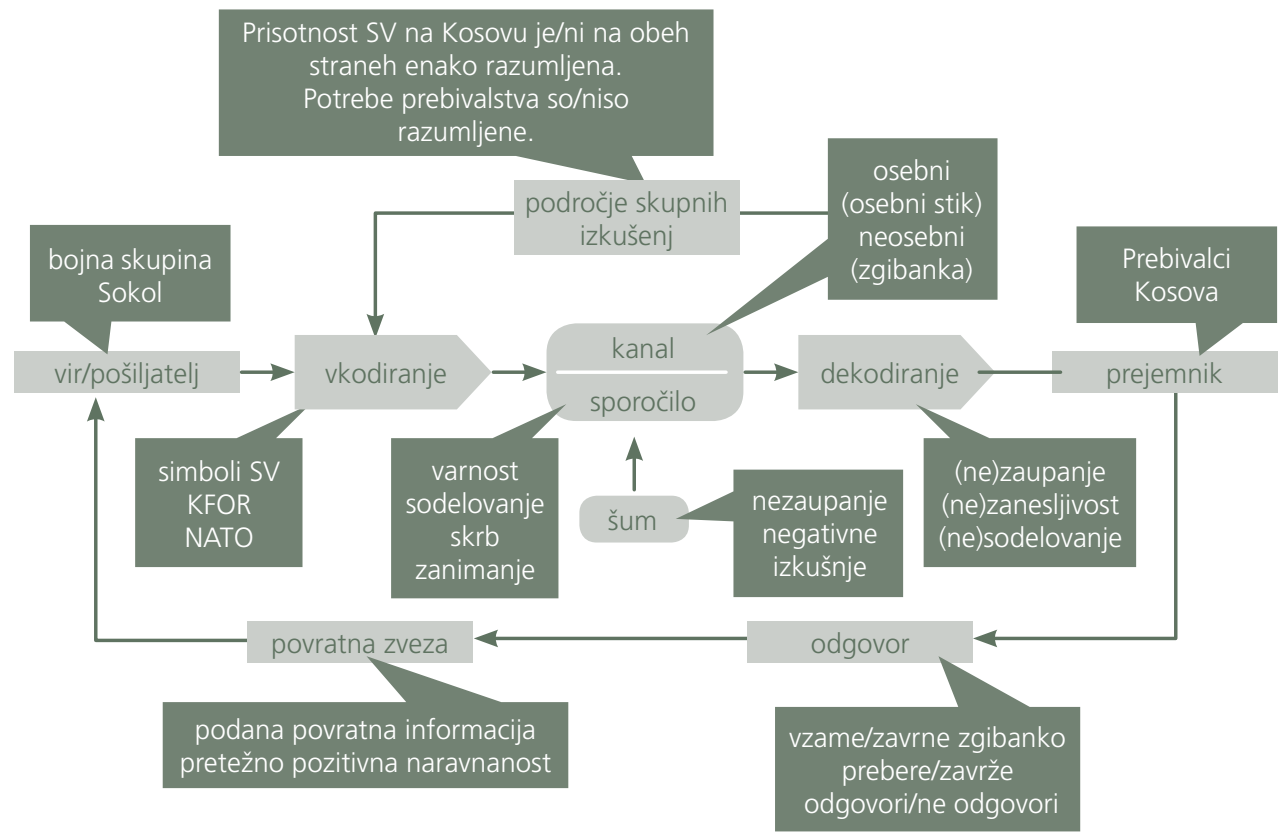

V tem primeru je šlo za prvi (samostojni) poskus izvajanja psihološkega delovanja na območju operacij kriznega odzivanja v takšni obliki. Sodeč po odzivnosti prebivalstva je bil dobro sprejet, saj je enota dobila veliko povratnih informacij, ki so bile večinoma pozitivne. Povratne informacije so se v kontingent vračale predvsem po dveh »kanalih«; (1) kot povsem konkretni odgovori na za to predvidenem delu zgibanke; (2) kot informacije, posredovane v osebnih stikih z vojaki, ki so svoje delo opravljali med prebivalstvom, ter prek poveljnika in ključnega osebja kontingenta, ki je imelo vzpostavljene odnose z vidnejšimi predstavniki skupnosti. Pripadniki slovenskega kontingenta so bili pogosto označeni kot prijazni, strpni, komunikativni in nenasilni. Da bi krepili pozitivno samopodobo in pripadnike še naprej spodbujali k pozitivno naravnanemu vedenju, so bili iz odrezkov zgibank izdelani plakati in objavljeni na javnem mestu. Tako je bila vzpostavljena »povratna zanka« transfera pozitivnih emocij, prikazanega na sliki 3 - pozitivne ocene so na (samo)percepcijo vojakov vplivale pozitivno in krepile njihovo pozitivno (prijazno) samopodobo (Škerbinc, 2013).

Čeprav enota ni imela osebja, specializiranega za posamezne segmente psihološkega delovanja, uspeh ni izostal, kar lahko pripišemo tudi skupni zgodovini, ki nam pogosto olajša vzpostavljanje stikov in razumevanje problematike v okolju, ter predhodnim izkušnjam. Seveda pa še tako dobre izkušnje in znanje ne bi odtehtale slabega priokusa, če bi pripadniki z neprimernim vedenjem rušili kredibilnost kontingenta, Slovenske vojske in zavezništva. 


\section{7 "PSYOPS« - VOJAŠKO ALI PSIHOLOŠKO DELOVANJE?}

\section{„Človek ne more polno živeti, ne da bi bil vpleten v psihološke procese, ki nas obkrožajo. ${ }^{11}$}

\section{Philip G. Zimbardo}

Članek se začenja z ugotovitvijo, da ima vsaka vojaška aktivnost tudi svojo psihološko dimenzijo. In po tem, ko smo se sprehodili skozi nekatere temeljne definicije, katerih vir je vojaška stroka, in pojme, ki so predvsem predmet psihologije, se ponovno vračamo na začetek. Je psihološko delovanje torej domena vojaške ali psihološke stroke?

Človekova narava - fiziologija, čustvovanje in mišljenje - se skozi tisočletja ni bistveno spreminjala. Prav tako se ne spreminjajo nekatera temeljna spoznanja o zaznavnih in višjih spoznavnih procesih, ki definirajo naše delovanje. Spreminjajo se le zunanje okoliščine, ki naše delovanje postavljajo v nove in nove kontekste, skozi katere se razvijamo in učimo. Vsa ta spoznanja se že od nekdaj s pridom (ali pa zlonamerno) uporabljajo na številnih področjih, od tržnega komuniciranja, menedžmenta, organizacije dela do delavnic osebne rasti, ki jih organizira lokalno društvo, in prodajalca, ki nas s ponarejenim nasmehom petnajstič v istem dnevu vpraša, kako smo, pa ga to sploh ne zanima.

Res pa je, da nas na področjih, ki so usmerjena k interdisciplinarnosti, vse prerado zanese v eno ali drugo smer, in predmet obravnave bodisi tiščimo stran od sebe, ker »to pa res ni naše področje, naj se s tem ukvarja ...«, bodisi vlečemo k sebi, saj »nihče drug ni kompetenten«. Podobno se dogaja s psihološkim delovanjem. Po eni strani ga je vse preveč preprosto poriniti psihologom, če ne zaradi drugega, zaradi predpone »psih-«, ob tem ko je psihologija le segment celotnega procesa delovanja. Prav tako so sprejemljivi argumenti, ki psihologe popolnoma izključujejo, ker gre »itak za povsem vojaško aktivnost«, ker so psihološke vsebine v primerjavi z vojaškimi nepomembne, in ker se »na psihologijo ja vsi spoznamo«. Vsi imamo namreč izkušnjo s čustvovanjem, mišljenjem, predsodki, vedenjem, kolektivi ... in torej lahko sklepamo na iste vsebine tudi pri drugih ljudeh, skupinah, kulturah, družbah itn. Ne nazadnje lahko v enačbo dodamo še vprašanje psihološke etike, saj se pojem psihološkega delovanja pogosto povezuje s »pranjem možganov«, manipuliranjem, zavajanjem ipd. Seveda gre pri tem za dejanja, s katerimi psihologi nikakor ne želimo biti povezani.

Dejstvo je, da se psihologija ne more ograditi od psihološkega delovanja, saj že definicije vse po vrsti vsebujejo pojme, kot so čustva, motivi, stališča, vplivanje, razumevanje in vedenje, ki so predmet psihologije. Arnejčič (2008) v svoji definiciji eksplicitno izpostavi neposredno povezavo, ko navaja $» / . . . /$ dejavnost v vojni in miru, ki uporablja spoznanja psihologije, da vpliva /.../«. Vsebine psihološkega delovanja oziroma propagande najdemo tudi v literaturi vojaške psihologije starejšega datuma;

\footnotetext{
"I "ne can't live mindfully without being enmeshed in psychological processes that are around us."
} 
vsaj v tisti, ki se področja psihologije v vojski loteva širše in se ne omejuje le na psihopatološke pojave. Arnautović v Vojni psihologiji, učbeniku za vojaške akademije nekdanje JLA iz leta 1988, psihološkim osnovam vojaške propagande namenja celo poglavje. Glede na dejstvo, da je slednje umeščeno med specifična področja vojaške psihologije ter pod okrilje specialne vojne, lahko sklepamo, da je vendar zaznana mejnost področja - ne moremo se delati, da se psihologije ne tiče, v bistvu pa spada v naloge drugih organizacijskih enot. Sicer pa se vsebina, če jo tehnološko malce posodobimo in odmislimo ideološko obarvano kolektivno kvaziparanojo pred vsem, kar bi lahko predstavljalo gnili kapitalizem, pogosto zelo približuje tisti, ki bi jo našli v kakšni novejši dokritni psihološkega delovanja. Lahko bi dejali, da so posamezni odseki skoraj enaki, avtor kot aktivnosti psihološke propagande pa opisuje tudi veliko takšnih, ki bi jih zdaj logično opredelili kot obveščevalno in/ali protiobveščevalno dejavnost.

Najbrž res nima pravega smisla, da bi le zaradi predpone sklepali, da gre pri psihološkem delovanju za aktivnosti psihološke dejavnosti, katere nosilec je psiholog. Ne nazadnje je velika večina nalog, ki jih psihološko delovanje vključuje, povsem praktičnih - ne zahtevajo posebnega strokovnega predznanja in bistveno bolje jih lahko opravi posameznik, ki obvlada specifične spretnosti (na primer delo z računalniško grafiko). Zagotovo pa obstaja »skupno polje izkušenj«, v katerem s spoznanji psihološke stroke lahko prispevamo tako k učinkovitosti delovanja kot tudi skrbi za etičnost posameznih aktivnosti. Takšna področja so predvsem:

- izobraževanje in usposabljanje iz psiholoških vsebin, ki bi prispevalo k (1) razumevanju psihodinamičnih pojavov v okoliščinah operacij kriznega odzivanja - tako tistih, ki so neposredno povezani z aktivnostmi psihološkega delovanja, kot tudi tistih, ki vplivajo na okoliščine misije, (2) prepoznavanju in vrednotenju etičnih dilem v procesih vplivanja, (3) poznavanju elementov in vsebin psihološkega raziskovanja ciljnih populacij ter (4) poznavanju postopkov evaluacije izdelkov;

- analiza ciljne populacije, ki pogosto temelji le na informacijah, ki so zunanjemu opazovalcu dostopne, in na tistih, na katere sklepa na podlagi osebnih okoliščin (izkušnje, vrednote, stališča, interesi, čustvovanje idr.), zanemarja pa psihodinamične procese na individualni in družbeni ravni. Posledično se dogajajo situacije, ki jih Ule in Kline (1996, str. 68), ko govorita o problemih sprejemanja in dekodiranja ter pomenu psihološkega raziskovanja ciljnih javnosti, poimenujeta »Srečal sem potrošnika in to nisem jaz! «;

- testiranje in evaluacija izdelka (izdelek se tu nanaša na vsebino in formo sporočila), pri čemer se srečujemo z nekaterimi osnovnimi tehnikami merjenja stališč - od anketnih listov do fokusnih skupin. Z neomejenimi sredstvi bi (vsaj teoretično) lahko uporabili tudi (v danih razmerah) bolj »znanstvenofantastične« metode, kot je spremljanje srčnega ritma, dihanja ali prevodnosti kože ob predvajanju dražljaja tako, kot raziskujejo za bolj učinkovito trženje različnih izdelkov. Psihologovo poznavanje tehnik bi lahko prispevalo k ustrezni izbiri in izvedbi. 
Če je vprašanje sodelovanja psihologov povezano z vprašanjem strokovne etike, se moramo vprašati, kako je to vprašanje rešeno na drugih področjih množičnega komuniciranja in predvsem marketinga. Res je, da je bila propaganda v preteklosti pogosto neposredno povezana z manipuliranjem, področje psihološkega delovanja pa se poskuša od tovrstnih aktivnosti ograditi. Če se vrnemo na uvod, v katerem je psihološko delovanje opredeljeno kot komponenta informacijskega delovanja, vidimo, da je zavajanje povsem ločena komponenta z lastnimi zmogljivostimi in metodami dela. Težnjo po transparentnem delovanju pa zasledimo v nekaterih osnovnih načelih, kot so verodostojnost, resnicoljubnost, atribucija vira, omejitve delovanja na lastne in zavezniške sile ipd.

Kaj pa drugi cilji, ki jim tovrstne aktivnosti sledijo, kot je obvarovanje življenj na eni in drugi strani? Pri psihološkem delovanju gre namreč za nekinetično delovanje in s tem manjšo možnost žrtev, kot smo že ugotovili na začetku, pa vzpostavljeno medsebojno zaupanje ščiti tudi naše pripadnike. Če lahko podležemo in vztrajamo pri ideji, da gre pri psihološkem delovanju vedno za manipulacijo, smo prebivalstvu odrekli posedovanje osnovnih sposobnosti presoje in se moramo sprijazniti z dejstvom, da smo tudi sami vsak trenutek žrtev takšnih ali drugačnih manipulacij. Sebi in drugim smo odrekli sanje o višjih ciljih, kakršen je »Kantov večni mir«. Človek je namreč družabno bitje, ki (večinoma) ne živi izolirano, in vsakokrat, ko vstopa v odnose z drugimi, je podvržen njihovim poskusom vplivanja in hkrati poskuša nanje vplivati sam.

In ne nazadnje je vprašanje etike vprašanje konkretnega posameznika in konkretnega primera oziroma aktivnosti. Tu pa si mora vsak psiholog ohraniti pravico, da $\mathrm{v}$ trenutku, ko presodi, da bo moral kršiti etični kodeks, svoje sodelovanje z ustrezno obrazložitvijo odkloni. Če kje, bo v primeru psihološkega delovanja moder poveljnik sprejemljiv za predloge o etičnih in moralnih omejitvah in psihologu nekoč hvaležen, ker mu je preprečil, da bi naredil napako. Za trenutek premislimo. So situacije, za katere lahko trdimo, da gre za manipulacijo in zlorabo, kot je primer Abu Graiba ${ }^{12}$, v katerih ne smemo sodelovati - še več, nanje moramo opozarjati in jih preprečevati. Kaj pa tiste, ob katerih naše sodelovanje lahko prispeva k preprečevanju žrtev na eni in drugi strani ali k omejevanju škode?

Trženje in psihologija tržnega komuniciranja? Vsekakor. V vojaškem okolju ne »tržimo« in naša dejavnost ni profitno naravnana, in prav tako bi težko v »trdno obliko« spravili proizvod, ki ga želimo spraviti v promet. Toda če odmislimo storitev ali izdelek in jo zamenjamo z idejo ali vrednotami, naša sporočila slej ko prej temeljijo na enakih psiho- in sociodinamičnih postulatih. Helmus et al. je študijo iz leta 2007 Enlisting Madison Avenue priročno podnaslovil The Marketing Approach to Earning Popular Support in Theaters of Operation in v njej nedvoumno potegnil vzporednico med aktivnostmi, ki jih izvaja vojska, in tistimi, ki potekajo v poslovnem svetu.

\footnotetext{
${ }_{12}$ V primeru Abu Graiba je ena izmed akterk pozneje v novinarski izjavi dejala, da jim je bilo ukazano, naj se za potrebe PSYOPS slikajo med nehumanim izživljanjem nad zaporniki. Ne glede na resnico gre v vsakem primeru (ali je res obstajal takšen ukaz ali pa je izjava neresnična) za okrutno in obsojanja vredno dejanje.
} 
Delo se začenja z mislimi, kot je »/.../ poslovne tržne prakse nudijo uporaben okvir za izboljšanje vojaških poskusov oblikovanja stališč in vedenja pri različnih populacijah /.../« (str. xvi), končuje pa z ugotovitvami, ki povsem neposredno nagovarjajo k uporabi marketinških strategij v vojaške namene: poznavanje ciljne populacije skozi proces segmentacije in ciljnega usmerjanja, razumevanje konceptov »brandinga«, uporaba vojske kot znamke, doseganje zadovoljstva civilnega prebivalstva - upravljanje in zadovoljevanje pričakovanj itn., če naštejemo le nekatere.

Prav tako nam je povezavo med koncepti psihologije tržnega komuniciranja uspelo nakazati skozi študijo primera.

Sklep Članek poskuša predstaviti nekatere temeljne značilnosti psihološkega delovanja, kot se izvaja v okviru sodobnih vojsk, oziroma poskusov vplivanja na ljudi izbranih ciljnih populacij, pa naj to imenujemo psihološko vojskovanje, vojna propaganda ali pa - psihologija potrošnika. Včasih se ob prebiranju vojaške literature zdi, da se poskuša psihološko delovanje predstaviti kot stroga vojaška veda, ki s civilnim okoljem in načinom delovanja nima nikakršne zveze, in da je težišče literature bolj kot na procesih v ozadju na obrazcih, navodilih in predlogah za izdelavo načrtov. A težko bomo obšli dejstvo, da poskusi vplivanja na izbrane ciljne populacije temeljijo na procesih, ki jih poznamo iz socialne psihologije. Dinamika v ozadju procesov je bolj ali manj enaka, ne glede na to, ali gre za prodajo izdelka, uveljavljanje znamke, kampanjo proti vožnji pod vplivom alkohola ali poskus pridobivanja podpore na območju mirovnih misij. Gre preprosto za to, da želimo stališča posameznikov spremeniti na način, da se bo spremenilo tudi njihovo vedenje - v prid naši ideji.

Tudi primer s Kosova, ki smo ga izpostavili in analizirali z vidika nekaterih osnovnih socialno psiholoških pojmov, dokazuje, da lahko procese, na katerih temelji sodobna potrošniška družba, povsem verodostojno uporabimo za namene vojaških aktivnosti na območjih mirovnih opreacij. Pri tem pa se moramo popolnoma ograditi od vseh primerov manipuliranja in zlorab.

Psihološko delovanje, nekinetično bojevanje, psihologija potrošnika itn.? Vse to. Le da ne prodajamo pralnega praška ali brivskih preparatov, temveč način življenja in ideale, ki se nam, ki nam ničesar ne manjka, zdijo samoumevni. Ljubljana: Fakulteta za družbene vede.

2. Arnautović, D. (et al.), 1988. Vojna psihologija. Beograd: Vojnoizdavački in novinski centar.

3. Bagozzi, Richard P. (et al.), 2002. The Social Psychology of Consumer Behaviour. Bukingham, Philadelphia: Open University Press.

4. Department of the Army. Psychological Operations Tactics, Techniques and Procedures. FM 3-05.301. Dostopno prek: http://www.fas.org 
5. Furlan, B. (et al.), 2006. Vojaška doktrina. Ljubljana: Defensor.

6. Helmus, Todd C. (et al.), 2007. Enlisting Madison Avenue: the Marketing Approach to Earning Popular Support in Theaters of Operation. RAND Corporation. Dostopno prek: http://www.rand.org.

7. Lamovec, T., 1988. Priročnik za psihologijo motivacije in emocij. Ljubljana: Filozofska fakulteta.

8. Larsen, Stephen C., 1999. Conducting Psychological Operations in Sophisticated Media Environments (magistrska naloga). Fort Leavenworth, ZDA: U.S Army Command and General Staff College.

9. Musek, J., 1988. Teorije osebnosti. Ljubljana: Filozofska fakulteta.

10. Musek, J., 1993. Znanstvena podoba osebnosti. Ljubljana; Educy d.o.o.

11. Paul, C., 2008. Information Operations: Doctrine and Practice. Westport, Connecticut: Praeger Security International.

12. Škerbinc, M., 2013. Osebni razgovor (9. 8. 2013).

13. Ule, M., 2005. Psihologija komuniciranja. Ljubljana: Fakulteta za družbene vede.

14. Ule, M., 2009. Socialna psihologija. Analitični pristop k življenju v družbi. Ljubljana: Fakulteta za družbene vede.

15. Ule, M. in Kline, M., 1996. Psihologija tržnega komuniciranja. Ljubljana: Fakulteta za družbene vede.

16. Zvonarević, M., 1984. Socijalna psihologija. Zagreb: Školska knjiga.

17. Canadian Forces. Psychological Operations: Joint Doctrine Manual. Dostopno prek: http://www.efd-cfd.forces.gc.ca.

18. USAF, Joint Chiefs of Staff. Doctrine for Joint Psychological Operations. Dostopno prek: http://www.dtic.mil.

19. United States Air Force. Psychological Operations: Air Force Doctrine Document 2-5.3. Dostopno prek: http://www.iwar.org.uk.

\section{Internetni viri}

20. Global Security.org - Reliable Security Information. Dostopno prek: http://www. globalsecurity.org (2. 3. 2009).

21. Psywarrior - Psychological Operations. Dostopno prek: http://www.psywarrior.com (2. 3. 2009).

22. RAND Corporation. Dostopno prek: http://www.rand.org (20. 3. 2009).

23. http://www.earlymoderntxts.com (10. 8. 2013).

24. http://www.eruditiononline.com (20. 3. 2009). 